\title{
Observations on Madagascan Amyrea Leandri and Tannodia Baill. (Euphorbiaceae)
}

\author{
Gordon McPherson
}

\begin{abstract}
McPHERSON, G. (2015). Observations on Madagascan Amyrea Leandri and Tannodia Baill. (Euphorbiaceae). Candollea 70: 141-144. In English, English and French abstracts. DOI: http://dx.doi.org/10.15553/c2015v701a11

Seven names for currently recognized taxa within Madagascan Amyrea Leandri and Tannodia Baill. (Euphorbiaceae) are discussed and reduced to synonymy, and in some cases in a different genus. Amyrea celastroides Radcl.-Sm. is synonymized under Amyrea humbertii Leandri, Amyrea eucleoides Radcl.-Sm. under Cleistanthus occidentalis (Leandri) Leandri, Amyrea maprouneifolia Radcl.-Sm. under Tannodia cordifolia Baill., Amyrea myrtifolia Radcl.-Sm. under Thecacoris perrieri Leandri, Amyrea stenocarpa Radcl.-Sm. under Amyrea humbertii Leandri, Tannodia grandiflora var. myrtifolia Radcl.-Sm. under Tannodia cordifolia Baill., and Tannodia nitida Radcl.-Sm. under Tannodia perrieri Baill.
\end{abstract}

\section{Résumé}

McPHERSON, G. (2015). Observations sur les genres Amyrea Leandri and Tannodia Baill. (Euphorbiaceae) à Madagascar. Candollea 70: 141-144. En anglais, résumés anglais et français. DOI: http://dx.doi.org/10.15553/c2015v701a11

Sept noms de taxons actuellement reconnus dans les genres Amyrea Leandri et Tannodia Baill. (Euphorbiaceae) à Madagascar sont discutés, mis en synonymie, et suivant les cas dans un genre différent. Amyrea celastroides Radcl.-Sm. est mis en synonymie sous Amyrea humbertii Leandri, Amyrea eucleoides Radcl.-Sm. sous Cleistanthus occidentalis (Leandri) Leandri, Amyrea maprouneifolia Radcl.-Sm. sous Tannodia cordifolia Baill., Amyrea myrtifolia Radcl.-Sm. sous Thecacoris perrieri Leandri, Amyrea stenocarpa Radcl.-Sm. sous Amyrea bumbertii Leandri, Tannodia grandiflora var. myrtifolia Radcl.Sm. sous Tannodia cordifolia Baill., et Tannodia nitida Radcl.-Sm. sous Tannodia perrieri Baill.

\section{Keywords}

EUPHORBIACEAE - Amyrea - Cleistanthus - Tannodia - Thecacoris - Madagascar 


\section{Introduction}

A review of the taxonomy of the genera Amyrea Leandri (Euphorbiaceae, Acalyphoideae) and Tannodia Baill. (Euphorbiaceae, Crotonoideae), done as part of an attempt to identify an accumulation of undetermined Madagascan specimens, has convinced me of the need to place into synonymy seven relatively recently published taxa. The two genera are considered together because they are often confused in the field, and sometimes in the herbarium, due to their similarly elongate, axillary, racemose to subspicate inflorescences and superficially similar leaves (SснAтz, 2001). In practice, flowering specimens can be separated generically by the presence in Tannodia of petals, whereas Amyrea lacks petals; fruiting specimens of Tannodia bear capsules covered by a short indument, but in Amyrea the capsules are glabrous. As well, the leaf blades in Tannodia are triplinerved (with one known exception), whereas in Amyrea the first pair of secondary veins does not usually arise at the base of the blade.

The new synonyms, all originating as currently recognized taxa within these two genera, are established and discussed below under the appropriate accepted species names. Data concerning all specimens examined can be consulted in the Madagascar Catalogue (2015).

\section{Taxonomy and nomenclature}

Amyrea humbertii Leandri in Notul. Syst. (Paris) 9: 169.1941.

Typus: Madagascar. Prov. Toamasina: Analamazaotra, 800 m, II.1919, Perrier de la Bâthie 9742 (lecto-: P [P00098119] image seen; isolecto-: P [P00098120] image seen) (lectotypified by Radcliffe-Smith, 1998b).

= Amyrea celastroides Radcl.-Sm. in Kew Bull. 53: 440. 1998. Typus: Madagascar. Prov. Toamasina: Forest reserve at Andasibe; wet evergreen forest, 20.XII.1988, Miller 3773 (holo-: P [P00098107] image seen; iso-: MO-3651586!), syn. nov.

= Amyrea stenocarpa Radcl.-Sm. in Kew Bull. 53: 451. 1998. Typus: Madagascar. Prov. Toamasina: Sahamamy, Perinet, 28.XII.1950, Service Forestier 2531 (holo-: P [P00098135] image seen; iso-: K [K000425610] image seen, MO-6570918!, P [P00098136] image seen, TEF [TEF000201] image seen), syn. nov.

Distribution and habitat. - Amyrea humbertii is widespread in Madagascar, from low to mid elevations in the eastern evergreen forests as well as from scattered localities in the central highlands and the western dry forests around Bemaraha.

Observations. - The diagnosis of $A$. celastroides states that it contrasts with $A$. humbertii in that it has wider leaves that are entire and thinly coriaceous, with thicker veins, as well as having longer inflorescences and smaller staminate disk glands. The holotype of $A$. celastroides does exhibit leaves in the stated 3-5 cm range, but in the lectotype of $A$. bumbertii the leaves are up to $4.8 \mathrm{~cm}$ wide, and thus not significantly different. The leaf margins of this lectotype appear to be as near to entire as do those of Miller 3773, although specimens of A. humbertii often do have evident marginal teeth. The thickness of the leaf venation of the two specimens does not appear to differ. Inflorescence lengths in specimens not otherwise distinguishable from $A$. humbertii sometimes attain $9 \mathrm{~cm}$, the maximum attributed to $A$. celastroides, and no difference in staminate disk gland size was observed in the 4 staminate flowering specimens examined.

In its diagnosis $A$. stenocarpa is distinguished from A. celastroides (placed above in the synonymy of $A$. humbertii) by its narrow fruit, $12 \times 7 \mathrm{~mm}$. The isotype at $\mathrm{MO}$ bears fruits that measure 8-11 $\times 6-7 \mathrm{~mm}$ and are almost certainly immature, with longitudinally collapsed walls and locule apices that project above the central axis of the fruit. The immature fruits of $A$. humbertii sometimes show the same longitudinally collapsed walls and extended locule apices, and its mature fruits measure c. $11 \times 11 \mathrm{~mm}$. Given that Service Forestier 2531 is not otherwise distinct from $A$. humbertii, which is common in the forests near Perinet, I have no doubt that this type specimen represents $A$. humbertii.

Cleistanthus occidentalis (Leandri) Leandri in Nat. Malgache 9: 45.1957.

$\equiv$ Cleistanthus stenonia var. occidentalis Leandri in Notul. Syst. (Paris) 11: 153. 1944.

Typus: Madagascar. Prov. Mahajanga: Plateau d'Antanimena (Boina), I.1924, Perrier de la Bâtbie 15928 (holo-: P [P00539586] image seen; iso-: P [P00252774]!).

= Amyrea eucleoides Radcl.-Sm. in Kew Bull. 53: 440. 1998. Typus: Madagascar. Prov. Mahajanga: Forêt à feuilles caduques sur calcaires de l'Antsingy, vers Ambodiriana (E. d'Antsalova), 21-27.I.1960, Leandri E Saboureau 2765 (holo-: P [P00098111] image seen; iso-: $\mathrm{G}$ [G00018199] image seen, K [K000425608] image seen, MO-04954355!, P [P00098112] image seen, WAG [WAG0004318] image seen), syn. nov.

Distribution and habitat. - Cleistanthus occidentalis is distributed in the western dry forests from Bemaraha to Boina.

Observations. - The type specimen of the new synonym is in fruit and bears infructescences from which the capsules have fallen, leaving remnants of the calyx and disk as well as the columns of the fallen fruit. On the MO isotype, several of these columns clearly display pairs of scars where two ovules were originally attached within each locule; the specimen thus 
represents a species belonging to either the Phyllanthaceae or the Picrodendraceae sensu APGIII (2009), rather than the Euphorbiaceae (where Amyrea is placed). The apparently fasciculate inflorescence type, the pubescent disk, and the stout column suggest Cleistanthus, and in fact this type specimen matches the rarely-collected $C$. occidentalis, known only from the region in which the specimen was found. It appears to be the first fruiting collection of that species.

Tannodia cordifolia Baill. in Adansonia 1: 251. 1861.

Typus: Comoro IsLAnds. Mayotte: M'sapéré Falls, 1850, Boivin s.n. (holo-: P [P00048240] image seen; iso-: $\mathrm{P}$ [00048241] image seen).

= Amyrea maprouneifolia Radcl.-Sm. in Kew Bull. 53: 447. 1998. Typus: Madagascar. Prov. Antsiranana: Sables à l'Ouest d'Ankerika (au S de l'embouchure de la Saharenana), 7.II.1966, Service Forestier 24533 (holo-: $\mathrm{P}$ [P00098122] image seen; iso-: MO-6570917!, P [P00399331 spirit]), syn. nov.

$=$ Tannodia grandiflora var. myrtifolia Radcl.-Sm. in Kew Bull. 53: 184. 1998. Typus: Madagascar. Prov. Antsiranana: Massif forestier, au SW de Marotaolana (Anivorano-Nord), 3 \& 6.III.1964, Service Forestier 23353 (holo-: K [K000422730] image seen; iso-: MO-04954357!, P [P00105931, P00105932] images seen, [P00399333 spirit]), TEF [TEF000223] image seen), syn. nov.

Distribution and habitat. - Tannodia cordifolia occurs in Madagascar and in the Comoro Islands (Mayotte). In Madagascar, it occurs in the North around the Marojejy massif, Daraina and Ankarana, and also in the Southwest around the Analavelona massif. This species is present in dry and subhumid tropical forest.

Observations. - The type specimen of Amyrea maprouneifolia bears only fruit, and thus has lost the petals that serve to most easily distinguish Tannodia from Amyrea. However, the specimen's tripliveined leaves and slightly verrucose, densely pubescent fruit would be unique in Amyrea but are typical of nearly all species of Tannodia. The 5 calyx lobes persisting beneath the fruit and the broadly obtuse leaf base mark the specimen as a small-leafed example of T. cordifolia.

On one fruit of the isotype of T. grandiflora var. myrtifolia at MO, parts of the 5 calyx lobes diagnostic (within Madagascan Tannodia) of T. cordifolia can be discerned, pubescent and ciliate as in typical specimens, whereas T. grandiflora was described as having two glabrous sepals. All other morphological features of Service Forestier 23353 also accord with $T$. cordifolia Baill.
Tannodia perrieri (Leandri) Radcl.-Sm. in Kew Bull. 53: 177. 1998.

$\equiv$ Domohinea perrieri Leandri in Bull. Soc. Bot. France 87: 285. 1940.

Typus: Madagascar. Prov. Toamasina: Forêt d'Analamazaotra, 800 m, XII.1911, Perrier de la Bâthie 9641 (lecto-: P [P00048239] image seen; isolecto-: K [K000422734, K000422735] images seen, P [P00098105, P00098106] images seen) (lectotypified by RadCLiffeSмітн, 1998a).

$=$ Tannodia nitida Radcl.-Sm. in Kew Bull. 53:178.1998. Typus: MADAGaScar. Prov. Toamasina: Forêt orientale, Massif de l'Ambohitsitondroina de Mahalevona (N. de la presqu'île Masoala), 3.XII.1954, Service Forestier 8710 (holo-: P [P00098102] image seen; iso-: K [K000422731] image seen, MO-6588150!, P [P00105978] image seen), syn. nov.

Distribution and habitat. - Tannodia perrieri is distributed throughout the east of Madagascar in mid to low elevation tropical evergreen forest.

Observations. - Tannodia nitida was distinguished by its author as having glossier, more markedly bi-coloured, and more strongly triplinerved leaves. However, the widely distributed T.perrieri displays enough variation in leaf lustre, colour, and venation to easily accommodate Service Forestier 8710, the type of T. nitida.

Thecacoris perrieri Leandri in Notul. Syst. (Paris) 6:19.1937.

Typus: Madagascar. Prov. Toamasina: Forêt d'Analamazaotra, 1400 m, 1911, Perrier de la Bâthie 2203 (holo-: P [P04778878] image seen; iso-: TAN [TAN000565] image seen).

= Amyrea myrtifolia Radcl.-Sm. in Kew Bull. 53: 447. 1998. Typus: Madagascar. Prov. Toamasina: Ilôt boisé du sommet de la montagne appelé Analavorikely, 29.XII.1944, Cours 2149 (holo-: P [P00098123] image seen; iso-: MO-5957215!, P [P00098124] image seen), syn. nov.

Distribution and habitat. - Thecacoris perrieri is widespread in Madagascar. The species is distributed along the east of Madagascar and in the Sambirano region, in tropical evergreen forest, and has also been identified from riverine and dry forest in the west and the north.

Observations. - The type specimen of Amyrea myrtifolia consists of a leafy twig bearing a few, somewhat weathered, infructescence axes and is accompanied by some unattached fruits. The biovulate nature of each locule, which would preclude the placement of the specimen in the Acalyphoideae with 
Amyrea, is thus not apparent. However, as in Thecacoris, the type has leaves that have an entire margin (vs at least obscurely dentate in Amyrea), lack a pair of small stipel-like structures at the base of the blade (present in Amyrea), and also lack scattered crater-like glands in the blade (present in Amyrea); as well, the column of the fruit is divided roughly equally into a thicker proximal portion and a thinner distal portion (the proximal portion is much shorter than the distal in those species of Amyrea for which the mature fruit is known). Furthermore, in leaf shape, indument, and other details this type specimen falls easily with the variation of Thecacoris perrieri.

\section{References}

APG [Angiosperm PHylogeny group] III (2009). An update of the Angiosperm Phylogeny Group classification for the orders and families of flowering plants: APG III. Bot. J. Linn. Soc. 161: 105-121.

Madagascar Catalogue (2015). Catalogue of the Vascular Plants of Madagascar. Missouri Botanical Garden, St. Louis \& Antananarivo [http://www.efloras.org/madagascar].

Radcliffe-Smith, A. (1998a). A synopsis of Tannodia Baill. (Crotonoideae-Aleuritideae-Grosserinae) with especial reference to Madagascar, and the subsumption of Domohinea Leandri. Kew Bull. 53: 173-186.

Radcliffe-Smith, A. (1998b). A synopsis of the genus Amyrea Leandri (Euphorbiaceae-Acalyphoideae). Kew Bull. 53: 437-451.

Schatz, G. E. (2001). Generic Tree Flora of Madagascar. Missouri Botanical Garden, St. Louis \& Royal Botanic Gardens, Kew. 